\title{
PERSPECTIVE OPEN Reassessing the projections of the World Water Development Report
}

\author{
Alberto Boretti $\mathbb{D}^{1,2}$ and Lorenzo Rosa $\mathbb{B}^{3,4}$
}

The 2018 edition of the United Nations World Water Development Report stated that nearly 6 billion peoples will suffer from clean water scarcity by 2050. This is the result of increasing demand for water, reduction of water resources, and increasing pollution of water, driven by dramatic population and economic growth. It is suggested that this number may be an underestimation, and scarcity of clean water by 2050 may be worse as the effects of the three drivers of water scarcity, as well as of unequal growth, accessibility and needs, are underrated. While the report promotes the spontaneous adoption of nature-based-solutions within an unconstrained population and economic expansion, there is an urgent need to regulate demography and economy, while enforcing clear rules to limit pollution, preserve aquifers and save water, equally applying everywhere. The aim of this paper is to highlight the inter-linkage in between population and economic growth and water demand, resources and pollution, that ultimately drive water scarcity, and the relevance of these aspects in local, rather than global, perspective, with a view to stimulating debate.

npj Clean Water (2019)2:15; https://doi.org/10.1038/s41545-019-0039-9

\section{INTRODUCTION}

The 2018 edition of the United Nations (UN) World Water Development Report (WWDR) ${ }^{1}$ has provided an update on the present trends of clean water availability and future expectations. Water security, the capacity of a population to safeguard sustainable access to adequate quantities of water of acceptable quality, is already at risk for many, and the situation will become worse in the next few decades. ${ }^{2}$ Clean water scarcity is a major issue in today's' world of 7.7 billion people. The strain on the water system will grow by 2050 when the world population will reach between 9.4 and 10.2 billion, a 22 to $34 \%$ increase. The strain will be aggravated by unequal population growth in different areas unrelated to local resources. Most of this population growth is expected in developing countries, first in Africa, and then in Asia, where scarcity of clean water is already a major issue.

At present, slightly less than one half of the global population, 3.6 billion people or $47 \%$, live in areas that suffer water scarcity at least 1 month each year. ${ }^{1}$ According to, ${ }^{3}$ the number is even larger, 4.0 billion people, or $52 \%$ of the global population. By 2050, more than half of the global population (57\%) will live in areas that suffer water scarcity at least one month each year. ${ }^{1}$ This estimate by ${ }^{1}$ may be an underestimation. The water demand, water resources, and water quality forecast by ${ }^{1}$ depends on many geopolitical factors that are difficult to predict. The decline of water resources and water quality only partially discussed in, ${ }^{1}$ may be much harder to control.

The WWDR ${ }^{1}$ focuses on the application of nature-basedsolutions (NBS), measures inspired by nature such as the adoption of dry toilets, which will have a negligible effect on the huge problem. More concrete regulatory measures are needed to tackle the clean water crisis, directly acting on water use and conservation. There are major obstacles to providing adequate water planning. First is the refusal to admit that unbounded growth is unsustainable. ${ }^{4}$ Overpopulation arguments are portrayed as "anti-poor", "anti-developing country" and "antihuman". ${ }^{4}$ Population size as a fundamental driver of scarcity is dubbed as a "faulty notion". ${ }^{5}$ This denial is partly responsible for lack of good water planning, supported by overconfidence in NBS. The key points of the WWDR ${ }^{1}$ are summarized and discussed in the following sections.

\section{WATER DEMAND BY 2050}

Increasing water demand follows population growth, economic development and changing consumption patterns. ${ }^{1}$ Global water demand has increased by $600 \%$ over the past 100 years. ${ }^{5}$ This corresponds to an annual increment rate of $1.8 \%$. According to, ${ }^{6}$ the present annual growth rate is less, only $1 \%$, but this figure may be optimistic. Global water demand will grow significantly over the next two decades in all the three components, industry, domestic and agriculture. ${ }^{1}$ Industrial and domestic demand will grow faster than agricultural demand but demand for agriculture will remain the largest. ${ }^{1}$ The growth in non-agricultural demand will exceed the growth in agricultural demand.

Global water demand for all uses, presently about $4,600 \mathrm{~km}^{3}$ per year, will increase by $20 \%$ to $30 \%$ by 2050 , up to 5,500 to 6,000 $\mathrm{km}^{3}$ per year. ${ }^{2}$ Global water demand for agriculture will increase by $60 \%$ by $2025 .^{8}$ By 2050 the global population will increase to between 9.4 to 10.2 billion people, an increment of $22 \%$ to $32 \%$. ${ }^{1}$ Most of the population growth will occur in Africa, +1.3 billion, or $+108 \%$ of the present value, and Asia, +0.75 billion, or $+18 \%$ of the present value. ${ }^{9}$ Two-thirds of the world population will live in

\footnotetext{
${ }^{1}$ Department for Management of Science and Technology Development, Ton Duc Thang University, Ho Chi Minh City, Vietnam; ${ }^{2}$ Faculty of Applied Sciences, Ton Duc Thang University, Ho Chi Minh City, Vietnam; ${ }^{3}$ University of Modena and Reggio Emilia, Department of Engineering Enzo Ferrari, Modena, Italy and ${ }^{4}$ Swinburne University of Technology, Centre for Microphotonics, Hawthorn, VIC, Australia

Correspondence: Alberto Boretti (albertoboretti@tdtu.edu.vn)
}

Received: 4 December 2018 Accepted: 14 June 2019

Published online: 31 July 2019 
cities. ${ }^{1}$ These estimates of future population and water demand are the best we have, though it is realized such forecasts are difficult. $^{5}$

Globally, water use for agriculture presently accounts for $70 \%$ of the total. Most are used for irrigation. Global estimates and projections are uncertain. ${ }^{1}$ The food demand by 2050 will increase by $60 \%,{ }^{1}$ and this increment will require more arable land and intensification of production. This will translate into increased use of water. ${ }^{10}$ Global use of water for industry presently accounts for $20 \%$ of the total. Energy production accounts for $75 \%$ of the industry total and manufacturing the remaining $25 \% .{ }^{11}$ Water demand for the industry by 2050 will increase everywhere around the world, with the possible exceptions of North America and Western Europe. ${ }^{5}$ Water demand for the industry will increase by $800 \%$ in Africa, where present industry use is negligible. Water demand for the industry will increase by $250 \%$ in Asia. Global water demand for manufacturing will increase by $400 \%$.

Global water use for energy will increase $20 \%$ over the period $2010-2035,{ }^{5}$ and by 2050 will increase by $85 \% .^{12}$ Domestic global water use currently accounts for $10 \%$ of the total. Domestic water demand is expected to increase significantly over the period 2010-2050 in all the world regions except for Western Europe. The greatest increment, 300\%, will occur in Africa and Asia. The increase will be $200 \%$ in Central and South America. ${ }^{5}$ This growth is attributed to the increase in water supply services to urban settlements. ${ }^{5}$

Clearly, the demand for water by 2050 will increase dramatically, but unequally, across all the continents. Quantitative estimates are difficult to provide with accuracy. The estimates of the WWDR $^{1}$ are not expected to be very accurate, and likely optimistic.

\section{WATER RESOURCES BY 2050}

Water demand cannot exceed water availability. While water demand is increasing, water availability is shrinking, because of shrinking resources and, as discussed in the next paragraph, pollution. The available surface water resources are forecast to remain about constant at continental level, ${ }^{5}$ although quality will deteriorate, and spatial and temporal distribution will change. More likely, aquifers will shrink, and salt intrusion in coastal areas will be very dramatic. In contrast, the growth of population, gross domestic product (GDP), and water demand will increase globally and unequally. ${ }^{5}$ Changes will be much more pronounced at the sub-regional level than at the country level, and the global average. $^{5}$

Many countries are already experiencing water scarcity conditions. ${ }^{13}$ Many more countries will face a reduced availability of surface water resources by $2050 .^{13}$ In the early to mid-2010s, 1.9 billion people, or $27 \%$ of the global population, lived in potential severely water-scarce areas. ${ }^{1}$ In 2050, this number will increase 42 to $95 \%$, or 2.7 to 3.2 billion peoples. ${ }^{1}$ If monthly, rather than annual, variability is considered, 3.6 billion people worldwide, slightly less than $50 \%$ of the global population, presently live in potential water-scarce areas at least 1 month per year. This number will increase from 33 to $58 \%$ to 4.8 to 5.7 billion by $2050 .^{13}$ About $73 \%$ of the people affected by water scarcity presently live in Asia. ${ }^{1}$

In the 2010s, groundwater use globally amounted to $800 \mathrm{~km}^{3}$ per year. ${ }^{5}$ India, the United States, China, Iran, and Pakistan accounted for $67 \%$ of the global extractions. ${ }^{5}$ Water withdrawals for irrigation are the primary driver of groundwater depletion worldwide. The increment of groundwater extractions by 2050 will be $1,100 \mathrm{~km}^{3}$ per year, or $39 \% .^{5}$ Improving the efficiency of irrigation water use may lead to an overall intensification of water depletion at the basin level. ${ }^{14}$ At about $4,600 \mathrm{~km}^{3}$ per year, current global withdrawals are already near maximum sustainable levels. ${ }^{15}$
More than $30 \%$ of the world largest groundwater systems are now in distress. ${ }^{16}$ The largest groundwater basins are being rapidly depleted. In many places, there is no accurate knowledge about how much water remains in these basins ${ }^{17}$ and. ${ }^{18}$ People are consuming groundwater quickly without knowing when it will run out, ${ }^{17}$ and. ${ }^{18}$ According to, ${ }^{19}$ the world's supply of fresh water may be much more limited than what is thought because unlimited groundwater was assumed. Challenges more severe than global are expected at regional and local scales. ${ }^{16}$

Coastal zones have special problems. They are more densely populated than the hinterland, and they exhibit higher population growth rates and urbanization. Water withdrawal is already causing significant land subsidence, that combined to thermosteric sea level rise, translate in relative sea level rise in coastal areas and salinization of aquifers, ${ }^{20-23}$ Water withdrawal-induced subsidence is reported in many coastal areas of the world, from North America, ${ }^{24-26}$ to East Asia, ${ }^{27-31}$ Population growth rates and urbanization in coastal areas are expected to further increase in the future, ${ }^{32,33}$ Thermo-steric and land subsidence driven relative sea level rise will also reduce arable lands along the coast and within estuaries, ${ }^{29,30}$ and reshape coastal regions. Especially coastal regions, which are home to a large and growing share of the global population, are undergoing an environmental decline $^{33}$ impacting water availability. The neglected dramatic changes of coastal areas, due to relative sea level rise by land subsidence and thermo-steric effects, that directly and indirectly affect water availability, are missing points in the WWDR. ${ }^{1}$

Coral islands are a special case, however affecting a small share of the global population, as they depend on a lens of groundwater for their water supply. Overuse of water causes shrinkage of the groundwater lens, which eventually leads to saltwater intrusion. Increasing population also leads to more contamination of the groundwater, so many islands are suffering a reduction in water resources as well as increasing pollution.

Apart from the discovery of new aquifers, desalination is the most effective measure to increase water resources. However, it is expensive, and it requires significant energy inputs. Currently, about $1 \%$ of the world's population living in coastal areas is dependent on desalination. The progress of desalination to 2050 is hard to predict, depending on economic and energetic energy issues.

The simple message is that water resources will decrease dramatically by 2050. Likely, the estimates of the WWDR ${ }^{1}$ are not very accurate, and probably optimistic.

\section{WATER QUALITY BY 2050}

The problem of water pollution is a weak part of the WWDR. ${ }^{1}$ Pollution is becoming worse, especially in the last few decades, but seems to be inadequately reported. Pollution of water is correlated with population density and economic growth. ${ }^{34}$ At present $12 \%$ of the world population drinks water from unimproved and unsafe sources. ${ }^{34}$ More than $30 \%$ of the world population, or 2.4 billion people, lives without any form of sanitation. ${ }^{34}$ Lack of sanitation contributes to water pollution. $90 \%$ of sewage in developing countries is discharged into the water untreated. ${ }^{35}$ Every year 730 million tons of sewage and other effluents are discharged into the water. ${ }^{36}$ Industry discharges 300 to 400 megatons of waste into the water every year.

Non-point source pollution from agriculture and urban areas and industry point source pollution contribute to the pollutant load. More than $30 \%$ of the global biodiversity has been lost because of the degradation of fresh-water ecosystems due to the pollution of water resources and aquatic ecosystems. ${ }^{37}$ Wastewater recycling in agriculture, that is important for livelihoods also brings serious health risks. ${ }^{1}$ Over the last 3 decades, water pollution has worsened, affecting almost every river in Africa, Asia and Latin America. ${ }^{38}$ 
Water pollution will intensify over the next few decades ${ }^{39}$ and become a serious threat to sustainable development. ${ }^{39}$ At present $80 \%$ of industrial and municipal wastewaters are released untreated. ${ }^{40}$ Effluents from wastewater are projected to increase because of rapid urbanization and the high cost of wastewater treatment. ${ }^{41}$ Nutrient loading is the most dangerous water quality threat, often associated with pathogen loading. ${ }^{38}$ Agriculture is the predominant source of nitrogen and a significant source of phosphorus. ${ }^{38}$ Current levels of nitrogen and phosphorus pollution from agriculture may already exceed the globally sustainable limits. ${ }^{42}$ Global fertilizer use is projected to increase from around 90 million tons in $2000^{43}$ to more than 150 million tons by $2050 .{ }^{44}$ Intensified biofuel production will lead to high nitrogen fertilizer consumption. ${ }^{43}$ Nitrogen and phosphorus effluents by 2050 will increase by $180 \%$ and $150 \%$ respectively. ${ }^{45}$ Other chemicals also impact on water quality. Global chemicals used for agriculture currently amount to 2 million tons per year, with herbicides $47.5 \%$, insecticides $29.5 \%$, fungicides $17.5 \%$ and other chemicals $5.5 \% .{ }^{46}$

The list of contaminants of concern is increasing, ${ }^{47}$ as a novel or varied contaminants are used, often suddenly detected at concentrations much higher than expected. ${ }^{47}$ Novel contaminants include pharmaceuticals, hormones, industrial chemicals, personal care products, flame retardants, detergents, perfluorinated compounds, caffeine, fragrances, cyanotoxins, nanomaterials and cleaning agents. ${ }^{47}$ Exposure to pollutants will increase dramatically in low-income and lower-middle income countries. ${ }^{38}$ Pollution will be driven by higher population and economic growth in these countries, ${ }^{38}$ and the lack of wastewater treatment. ${ }^{40}$ Pollution will be particularly strong in Africa. ${ }^{38}$

In brief, the demand for water will increase by 2050 but the availability of water will be reduced. Water resources will reduce. Pollution will further reduce the amount of clean fresh water. This aspect is marginally factored in the WWDR. ${ }^{1}$

\section{OTHER ECOLOGICAL CHANGES BY 2050}

Changes in the ecosystems will be affected by changes in the water demand and availability and vice versa. Conservation or restoration of the ecosystems will impact on water availability for human consumption, both resources, and quality. ${ }^{1}$ About $30 \%$ of the global land area is forested, and $65 \%$ of this area is already in a degraded state. ${ }^{48}$ Grasslands and areas with trees, but dominated by grass, presently exceed the area of forests. Large areas of forests and wetlands have been converted into grasslands, for livestock grazing or production of crops. Wetlands only cover $2.6 \%$ of the land but play a significant role in hydrology. ${ }^{49}$

The loss of natural wetland area has been $87 \%$ since 1700 . The rate of wetland loss has been $370 \%$ faster during the $20^{\text {th }}$ and early 21 st centuries. ${ }^{49}$ Since 1900 there has been a loss of $64 \%$ to $71 \%$ of wetlands. ${ }^{49}$ Losses have been larger, and are now faster, for inland, rather than coastal, wetlands. ${ }^{49}$ The rate of loss is presently highest in Asia. The effects of sea level rise are underrated in. 49

Soils are also changing. Most of the world's soils are in only fair, poor or very poor condition, ${ }^{50}$ and the situation is expected to worsen in the future. ${ }^{50}$ The major global issues are soil erosion, loss of soil organic carbon and nutrient imbalance. Presently, soil erosion from croplands carries away 25 to 40 billion tons of soil every year. Crop yields and soil's ability to regulate water, carbon, and nutrients are reduced. 23 to 42 million tons of nitrogen and 15 to 26 million tons of phosphorus are presently transported off the land. Soil erosion and nutrient run-off have negative effects on water quality. ${ }^{50}$ Sodicity and salinity of the soils are global issues in both irrigated and non-irrigated areas. Sodicity and salinity take out 0.3 to 1.5 million ha of farmland each year. ${ }^{50}$ The production potential is also reduced by 20 to 46 million ha. ${ }^{50}$

Ecosystems, biodiversity, and soil degradation are expected to continue to 2050, at an ever-faster rate. This will have an impact on the availability and quality of water, which is only partially considered in the WWDR. ${ }^{1}$

\section{DISCUSSION}

The data presented in, ${ }^{1}$ provide an optimistic, but still dramatic, estimation of water scarcity by 2050 . Their gentle, nature-basedsolutions (NBS) are quite inadequate to tackle this serious problem. Limitation of population and economic growth cannot be enforced easily. Ad hoc responses seem to be necessary but hard to be implemented.

Figure 1 presents in (a) the global water withdrawal, the GPD pro-capita and the world population since the year 1900, and in (b) the population of the world and of selected countries of Asia and Africa since the year 1950. The figure also presents in (c) the graphical concept of water scarcity, resulting from a more than linear growing demand, and a similarly more than linear reducing availability of clean water. It is intuitive that growing demand and shrinking availability will ultimately cross each other, locally earlier than globally.

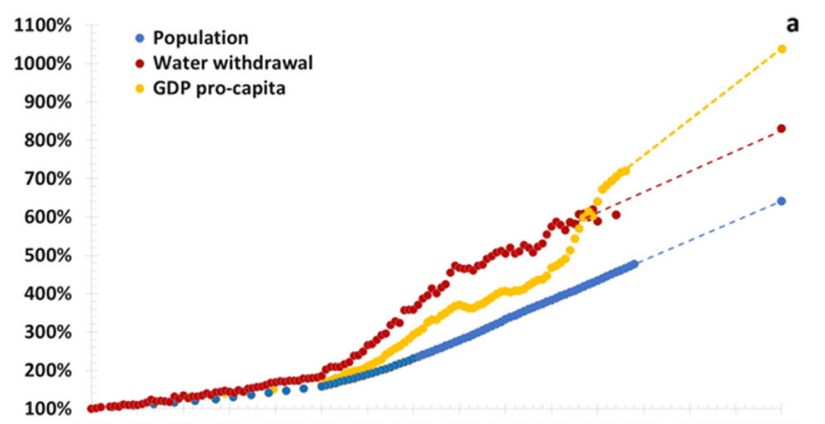

1900191019201930194019501960197019801990200020102020203020402050
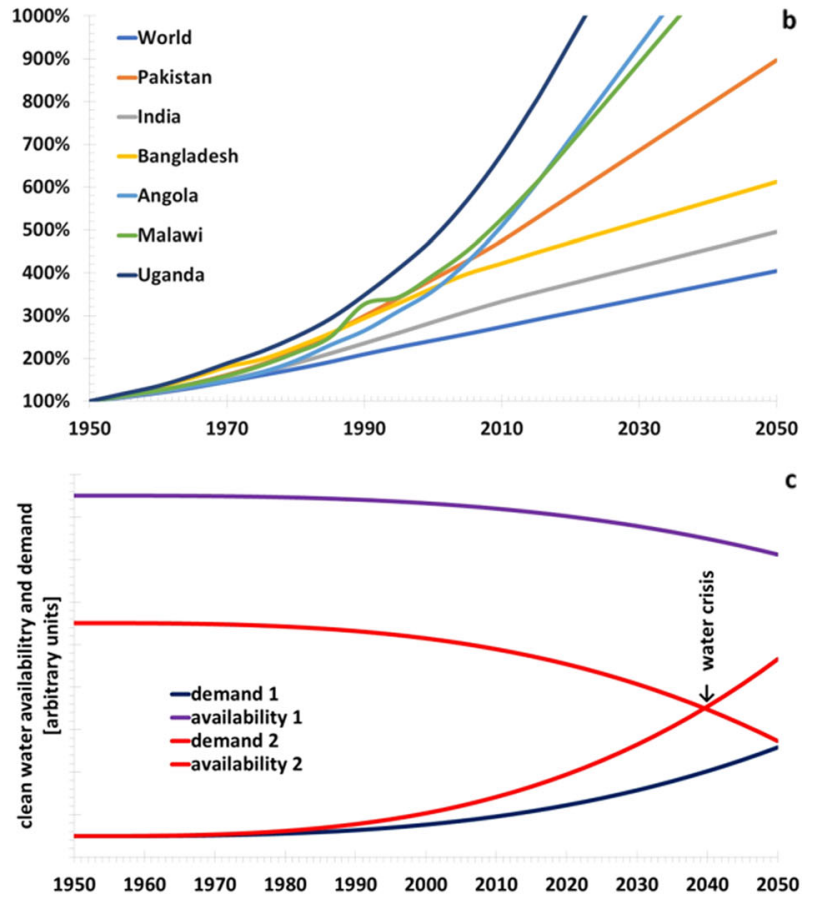

Fig. 1 a Water withdrawal, GDP pro-capita, and world population. The water withdrawal data to 2014 is from. ${ }^{71}$ The GPD pro-capita data to 2016 is from. ${ }^{73}$ The population data to 2018 is from. ${ }^{72}$ b The population of the world and selected countries of Asia and Africa. The data to 2018 is from ref. ${ }^{72}$ The values for 2050 are obtained by linear extrapolations from recent years. c Graphical concept of water scarcity, resulting from a more than linear growing demand and a similarly more than a linear reduction of clean water availability 
Demand for water, same of food or energy, increases with the growth of population and gross domestic product (GDP) procapita. ${ }^{51}$ In addition to the growth of population, also the generation of wealth worldwide translates in increased consumption, resulting in increased water demand. The expected changes in wealth are coupled to alterations in the consumption patterns, including changes to diet. As agriculture worldwide accounts for up to $70 \%$ of the total consumption of water, ${ }^{52-55}$ with much higher levels in arid and semi-arid regions, food and water demands are on a collision path. One example of conflicting demands for water, food, and energy, within a context of regional population and economic growth, is the Mekong Delta. The morphology of the Mekong Delta as we know today developed in between 5.5 and 3.5 ka (thousand years before present). The relatively stable configuration experienced during the last $3.5 \mathrm{ka}$ has been dramatically undermined during the last few decades. The delta itself may completely disappear in less than one century.

The increased demand for food, water, and energy of a growing population and a growing economy has translated in the extraction of larger quantities of groundwater in the delta, the construction of hydroelectric dams along the course of the river, the diverted water flow for increased upstream water uses, and the riverbed mining for sand. The reduced flow of water and sediments to the delta, ${ }^{56-60}$ coupled to the subsidence from excessive groundwater withdrawal and soil compaction, ${ }^{58,61-65}$ and the thermo-steric sea level rise, ${ }^{66,68,74}$ have translated in the sinking and shrinking of the delta. In the short term, this has translated in salinization of coastal aquifers, depletion of aquifers, and arsenic pollution of deep groundwater, additional to salinization of soil, flooding, destruction of rice harvesting and depletion of wild fish stocks, impacting on water and food availability, ${ }^{67,68}$ In the longer term, the delta itself may completely disappear as the result of not sustainable growth. 69,70

As previously mentioned, apart from the discovery of new aquifers, increased use of desalination and water purification may lessen the reduction of available water. However, desalination needs significant economic and energetic energy input, difficult to predict. The water withdrawal data is obtained from. ${ }^{71}$ The population data is obtained from. ${ }^{72}$ The GPD pro-capita data is obtained from. ${ }^{73}$ The values by 2050 are obtained by linear extrapolations. The global water withdrawal is correlated to the world population, but it has been growing faster than the world population. The GPD pro-capita has been growing even faster than the world population. While we do not have any reliable data on water quality and resources vs. time, over the same time window, we expect that the water quality and resources have also been deteriorating more than proportionally to the economic and population growth.

Use of fertilizers has grown even faster than the global water withdrawal. ${ }^{74}$ Production and consumption of nitrogen, phosphate and potash fertilizers since 1961 has similar growing patterns. ${ }^{75}$ Global pesticide production is also growing continuously. $^{76}$ The key driver for pollution is the growth of the population and the economy. ${ }^{41}$ The groundwater basins are being quickly exhausted by excessive withdrawals. Additionally, because of the relative sea level rise, thermo-steric and groundwater withdrawal generated subsidence, aquifers in coastal lands and estuaries are being rapidly compromised, while fertile lands are turned unproductive, ${ }^{29,30}$ Similarly, to water demand, also water resources and water quality are thus linked to economic and demographic growths. Opposite to the population and GDP data, the data of fresh water usage, fresh-water resources, and pollution of fresh water, are more difficult to be sorted out with the accuracy needed, making every forecast to 2050 problematic.

Regarding the economy, it must be added that the IMF's Global Debt Database ${ }^{77}$ indicates that the debt has reached globally in 2017 an all-time high of $\$ 184$ trillion, or $225 \%$ of the GDP. The world's debt now exceeds $\$ 86,000$ per capita, which is more than
$250 \%$ of the average income per capita. The most indebted economies in the world are the richer ones, with the United States, China, and Japan accounting for more than half of the global debt, and the poorer countries on their way to becoming indebted.

The three key aspects of water scarcity, water demand, water resources, water pollution, are strongly related to population growth and economic growth. They are strongly interconnected, and dramatically variable in space and time, with local conditions that will be much worse than the global conditions. Many countries are experiencing population growth largely exceeding the already alarming global average. Linear extrapolations to 2050 are in some cases in excess, and in some cases in defect, of the values forecast in, ${ }^{72}$ demonstrating complex dynamics. For example, the population forecast to 2050 for Uganda is $105,698,201$, or $+2,110 \%$ vs. the values of 1950 . The linear extrapolation to 2050 is $89,313,923$, or $+1,783 \%$ vs. the values of 1950. Opposite, the population forecast to 2050 for the world is, optimistically, $9,771,822,753$, or $+385 \%$ vs. the values of 1950 . The linear extrapolation to 2050 is $10,274,650,493$, or $+405 \%$ vs. the values of 1950 . Global growths of 385 to $405 \%$ over 100 years are everything but sustainable. Even less sustainable are local growths that at the country level are exceeding $2,000 \%$ over 100 years. It is impossible to provide clean fresh water to support such growth rates.

As clean water demand is increasing, and clean water availability is reducing, with local situations much worse than global, clean water demand will eventually exceed the availability of clean water at some local levels much earlier than at the global level. These break-points may occur earlier than 2050 in many areas of the world. Considering when a vital resource is in short supply, people will fight for it, provision of water to 2050 will be very likely played against a social background of competition and probably conflict if nothing will be done to prevent a water crisis.

\section{CONCLUSIONS}

The paper has discussed the correlation between the exponential growth in global population and GDP and water scarcity, that is the result of the competing water demand, water resources, and water pollution. Population and economic growth to 2050 will be very likely strong, and unequal across the globe, with the largest growth rates expected in third world countries. Water demand to 2050 will grow even more than the population and the economy, same of the reduction of water quality and resources. Local patterns will be more critical than global patterns, making the problem more difficult to be solved.

Water is ultimately a finite resource and the marginal solutions for water scarcity currently being proposed in the United Nations (UN) World Water Development Report (WWDR) will prove hopelessly inadequate by 2050 in the absence of any serious effort to tackle these underlying truths. Improvements in the science and technology of water treatment, water management and clean water supply, and in the awareness of water conservation and savings, while developing nature-basedsolutions (NBS), may certainly alleviate future clean water scarcity. However, a better policy is much more urgent than scientific, technological and philosophical advances, as this will not be enough. There is a clear regulatory promulgation and enforcement issue especially in the developing countries that needs to be addressed the sooner the better. We need the political will to enforce global regulations, especially where economies and population are building up, as unregulated development is not sustainable anymore.

There is no specific remedial measure to propose, if not to support more sustainable population and economic growths, with local rather than global focus, keeping in mind that growth cannot be infinite in a finite world. As the Economist Kenneth Boulding declared to the United States Congress ${ }^{78}$ "Anyone who believes 
exponential growth can go on forever in a finite world is either a madman or an economist". However, as noted in, ${ }^{79}$ the pursuit of economic growth has been the prevalent policy goal across the world for the past 70 years. The aim of this paper is simply to highlight the connection between population and economic growth and water demand, resources and pollution, that ultimately drive water scarcity, and the relevance of these aspects in local, more than global perspective, to stimulate an urgent and comprehensive debate.

\section{ACKNOWLEDGEMENTS}

We thank Cliff Ollier and Pamela Matlack-Klein for the comments and suggestions provided.

\section{AUTHOR CONTRIBUTIONS}

A.B. designed the manuscript, selecting the references, assembling the materials, processing the data, and organizing the first draft. L.R. then contributed to the writing of the manuscript. A.B. then further changed the manuscript addressing the reviewers' comments.

\section{ADDITIONAL INFORMATION}

Competing interests: The authors declare no competing interests.

Publisher's note: Springer Nature remains neutral with regard to jurisdictional claims in published maps and institutional affiliations.

\section{REFERENCES}

1. World Water Assessment Programme (Nations Unies), The United Nations World Water Development Report 2018 (United Nations Educational, Scientific and Cultural Organization, New York, United States) www.unwater.org/publications/ world-water-development-report-2018/. (2018).

2. Burek, P. et al. Water Futures and Solution: Fast Track Initiative (Final Report). IIASA Working Paper (International Institute for Applied Systems Analysis (IIASA), Laxenburg, Austria, 2016).

3. Mekonnen, M. M. \& Hoekstra, A. Y. Four billion people facing severe water scarcity. Sci. Adv. 2, e1500323 (2016).

4. Kopnina, H. \& Washington, H. Discussing why population growth is still ignored or denied. Chin. J. Popul. Resour. Environ. 14, 133-143 (2016).

5. Wada, Y. et al. Modelling global water use for the 21st century: The Water Futures and Solutions (WFaS) initiative and its approaches. Geosci. Model Dev. 9, 175-222 (2016).

6. Food And Agriculture Organization of the United Nations (FAO), AQUASTAT Www fao.org/nr/aquastat/. (2018).

7. Rosegrant, M. W., Cai, X. \& Cline, S. A. World Water and Food to 2025: Dealing with Scarcity (International Food Policy Research Institute (IFPRI), Washington, DC, 2002).

8. Alexandratos, N. \& Bruinsma, J. World Agriculture Towards 2030/2050: The 2012 Revision. ESA Working paper No. 12-03. Rome, Food and Agriculture Organization of the United Nations (FAO) www.fao.org/docrep/016/ap106e/ap106e.pdf. (2012).

9. United Nations Department of Economic and Social Affairs (UNDESA), World Population Prospects: Key Findings and Advance Tables - The 2017 Revision. Working Paper No. ESA/P/WP/248 (UNDESA, Population Division, New York, 2017). www.esa.un.org/unpd/wpp/Publications/Files/WPP2017_KeyFindings.pdf.

10. Leadley, P. W. et al. Progress towards the Aichi Biodiversity Targets: An Assessment of Biodiversity Trends, Policy Scenarios and Key Actions. CBD Technical Series No. 78. (Secretariat of the Convention on Biological Diversity, Montreal, PQ, 2014). www. cbd.int/doc/publications/cbd-ts-78-en.pdf.

11. United Nations World Water Assessment Programme (WWAP). The United Nations World Water Development Report 2014 (Water and Energy. Paris, UNESCO, 2014). unesdoc.unesco.org/images/0022/002257/225741E.pdf.

12. International Energy Agency (IEA). Water for Energy: Is Energy Becoming a Thirstier Resource? Ch. 17 (World Energy Outlook 2012. Paris, IEA, 2012). www.iea.org/ publications/freepublications/publication/WEO2012_free.pdf.

13. Veldkamp, T. I. E. et al. Water scarcity hotspots travel downstream due to human interventions in the $20^{\text {th }}$ and $21^{\text {st }}$ century. Nat. Commun. 8, 15697 (2017).

14. Huffaker, R. Conservation potential of agricultural water conservation subsidies. Water Resour. Res. 44, W00E01 (2008)
15. Gleick, P. H. \& Palaniappan, M. Peak water limits to freshwater withdrawal and use. Proc. Natl Acad. Sci. 107, 11155-11162 (2010).

16. Richey, A. S. et al. Quantifying renewable groundwater stress with GRACE. Water Resour. Res. 51, 5217-5238 (2015).

17. Scanlon, B. R. et al. Global evaluation of new GRACE mascon products for hydrologic applications. Water Resour. Res. 52, 9412-9429 (2016).

18. Richey, A. S. et al. Uncertainty in global groundwater storage estimates in a total groundwater stress framework. Water Resour. Res. 51, 5198-5216 (2015).

19. Ferguson, G., McIntosh, J. C., Perrone, D. \& Jasechko, S. Competition for shrinking window of low salinity groundwater. Environ. Res. Lett. 13, article114013 (2018).

20. Werner, A. D. \& Simmons, C. T. Impact of sea-level rise on sea water intrusion in coastal aquifers. Groundwater 47, 197-204 (2009).

21. Ferguson, G. \& Gleeson, T. Vulnerability of coastal aquifers to groundwater use and climate change. Nat. Clim. Change 2, 342 (2012).

22. Adepelumi, A. A., Ako, B. D., Ajayi, T. R., Afolabi, O. \& Omotoso, E. J. Delineation of saltwater intrusion into the freshwater aquifer of Lekki Peninsula, Lagos, Nigeria. Environ. Geol. 56, 927-933 (2009).

23. Lee, C. H. \& Cheng, R. T. S. On seawater encroachment in coastal aquifers. Water Resour. Res. 10, 1039-1043 (1974).

24. Galloway, D. L., Jones, D. R. \& Ingebritsen, S. E. Land Subsidence in the United States Vol. 1182, (US Geological Survey, Denver, United States, 1999).

25. Davis, G. H. Land subsidence and sea level rise on the Atlantic Coastal Plain of the United States. Environ. Geol. Water Sci. 10, 67-80 (1987).

26. Holzer, T. L. \& Galloway, D. L. Impacts of land subsidence caused by withdrawal of underground fluids in the United States. Hum. Geol. agents 16, 87 (2005).

27. Xue, Y. Q., Zhang, Y., Ye, S. J., Wu, J. C. \& Li, Q. F. Land subsidence in China. Environ. Geol. 48, 713-720 (2005).

28. Wang, $H$. et al. InSAR reveals coastal subsidence in the Pearl River Delta, China. Geophys. J. Int. 191, 1119-1128 (2012).

29. Erban, L. E., Gorelick, S. M. \& Zebker, H. A. Groundwater extraction, land subsidence, and sea-level rise in the Mekong Delta, Vietnam. Environ. Res. Lett. 9 084010 (2014).

30. Minderhoud, P. S. J. et al. Impacts of 25 years of groundwater extraction on subsidence in the Mekong delta, Vietnam. Environ. Res. Lett. 12, 064006 (2017).

31. Phi, T. H. \& Strokova, L. A. Prediction maps of land subsidence caused by groundwater exploitation in Hanoi, Vietnam. Resour.-Effic. Technol. 1, 80-89 (2015).

32. Neumann, B., Vafeidis, A. T. Zimmermann, J. \& Nicholls, R. J. Future coastal population growth and exposure to sea-level rise and coastal flooding-a global assessment. PLOS ONE 10, e0118571 (2015).

33. Creel, L. Ripple Effects: Population and Coastal Regions (1-7) (Population Reference Bureau, Washington, DC, 2003).

34. Unicef, W. H. O. 2015 Progress on Sanitation and Drinking Water-2015 Update and MDG Assessment (JM Program, Geneva, Switzerland, 2016).

35. World Health Organization, WHO/UNICEF Joint Water Supply and Sanitation Monitoring Programme. Progress on sanitation and drinking water: 2015 update and MDG assessment (World Health Organization, New York, United States, 2015).

36. Connor, R. et al. The United Nations world water development report 2017. Wastewater: The untapped resource. The United Nations World Water Development Report (United Nations Educational, Scientific and Cultural Organization, New York, United States, 2017).

37. United Nations, UN Water. Wastewater Management-A UN-Water Analytical Brief 1-52 (World Meteorological Organization, Geneva, Switzerland, 2015). www. unwater.org/publications/wastewater-management-un-water-analytical-brief/.

38. United Nations Environment Programme (UNEP). A Snapshot of the World's Water Quality: Towards a Global Assessment (UNEP, Nairobi, 2016). uneplive.unep.org/ media/docs/assessments/unep_wwqa_report_web.pdf.

39. Veolia/IFPRI (International Food Policy Research Institute), The Murky Future of Global Water Quality: New Global Study Projects Rapid Deterioration in Water Quality (IFPRI/Veolia, Washington DC/Chicago, III., 2016) www.ifpri.org/ publication/murky-future-global-water-quality-new-global-study-projects-rapiddeterioration-water (2016).

40. Sebastian, F. P. Purified Wastewater: The Untapped Water Resource. J. Water Pollut. Control Fed. 46, 239-246 (1974).

41. European Environment Agency, Increasing Environmental Pollution (GMT 10) www.eea.europa.eu/soer-2015/global/pollution (2015).

42. Rockström, J. et al. A safe operating space for humanity. Nature 461, 472-475 (2009).

43. Winiwarter, W., Erisman, J. W., Galloway, J. N., Klimont, Z. \& Sutton, M. A. Estimating environmentally relevant fixed nitrogen demand in the 21st century. Clim. Change 120, 889-901 (2013).

44. Kray, H. A. Farming for the Future. The Environmental Sustainability of Agriculture in a Changing World pubdocs.worldbank.org/en/862271433768092396/HolgerKray-RO-SustainableAg-hkray-ENG.pdf. (2012). 
45. Organisation for Economic Co-operation and Development (OECD). OECD Environmental Outlook to 2050 (Organisation for Economic Co-operation and Development, Paris, France, 2012). www.oecd.org/env/indicators-modelling-outlooks/ oecdenvironmentaloutlookto2050theconsequencesofinaction-keyfactsand figures.htm.

46. De, A., Bose, R., Kumar, A. \& Mozumdar, S., Targeted Delivery of Pesticides Using Biodegradable Polymeric Nanoparticles (Springer Briefs in Molecular Science, India, 2014).

47. Sauvé, S. \& Desrosiers, M. A review of what is an emerging contaminant. Chem. Cent. J. 8, 15 (2014).

48. Food and Agriculture Organization of the United Nations (FAO). Global Forest Resources Assessment 2015: How are theWorld's Forests Changing? Second edition (FAO, Rome, 2016). www.fao.org/3/a-i4793e.pdf.

49. Davidson, N. C. How much wetland has the world lost? Long-term and recent trends in global wetland area. Mar. Freshw. Res. 65, 934-941 (2014).

50. Food and Agriculture Organization of the United Nations/Intergovernmental Technical Panel on Soils (AO/ITPS). Status of the World's Soil Resources (SWSR) Main Report. (FAO, Rome, 2015). www.fao.org/3/a-i5199e.pdf.

51. World Bank Group, Economic Growth, Convergence, and World Food Demand and Supply. openknowledge.worldbank.org/handle/10986/28918. (2017).

52. Worldometers. Water Consumption Statistics www.worldometers.info/water/. (2019).

53. Organisation for Economic Co-operation and Development (OECD), Water and Agriculture www.oecd.org/agriculture/topics/water-and-agriculture/. (2017).

54. Food And Agriculture Organization of the United Nations (FAO), Water for Sustainable Food and Agriculture www.fao.org/3/a-i7959e.pdf. (2017).

55. World Bank Group. Water in Agriculture www.worldbank.org/en/topic/water-inagriculture. (2017)

56. Kondolf, G. M., Rubin, Z. K. \& Minear, J. T. Dams on the Mekong: cumulative sediment starvation. Water Resour. Res. 50, 5158-5169 (2014).

57. Van Manh, N. et al. Future sediment dynamics in the Mekong Delta floodplains: Impacts of hydropower development, climate change and sea level rise. Glob. Planet. Change 127, 22-33 (2015).

58. Zoccarato, C., Minderhoud, P. S. \& Teatini, P. The role of sedimentation and natural compaction in a prograding delta: insights from the mega Mekong delta, Vietnam. Sci. Rep. 8, 11437 (2018).

59. Anthony, E. J. et al. Linking rapid erosion of the Mekong River delta to human activities. Sci. Rep. 5, 14745 (2015).

60. Brunier, G., Anthony, E. J., Goichot, M., Provansal, M. \& Dussouillez, P. Recent morphological changes in the Mekong and Bassac river channels, Mekong Delta: The marked impact of river-bed mining and implications for delta destabilisation. Geomorphology 224, 177-191 (2014).

61. Erban, L. E. \& Gorelick, S. M. Closing the irrigation deficit in Cambodia: Implications for transboundary impacts on groundwater and Mekong River flow. J. Hydrol. 535, 85-92 (2016).

62. Erban, L. E., Gorelick, S. M., Zebker, H. A. \& Fendorf, S. Release of arsenic to deep groundwater in the Mekong Delta, Vietnam, linked to pumping-induced land subsidence. Proc. Natl Acad. Sci. 110, 13751-13756 (2013).

63. Minderhoud, P. S. J., Erkens, G., Pham, V. H., Vuong, B. T. \& Stouthamer, E. Assessing the potential of the multi-aquifer subsurface of the Mekong Delta (Vietnam) for land subsidence due to groundwater extraction. Proc. Int. Assoc. Hydrol. Sci. 372, 73-76 (2015).
64. Li, X., Liu, J. P., Saito, Y. \& Nguyen, V. L. Recent evolution of the Mekong Delta and the impacts of dams. Earth Sci. Rev. 175, 1-17 (2017).

65. Minderhoud, P. S. J. et al. The relation between land use and subsidence in the Vietnamese Mekong Delta. Sci. Total Environ. 634, 715-726 (2018).

66. Dang, T. D., Cochrane, T. A. \& Arias, M. E. Future hydrological alterations in the Mekong Delta under the impact of water resources development, land subsidence and sea level rise. J. Hydrol. Reg. Stud. 15, 119-133 (2018).

67. Khat, H. V., Dang, N. H. \& Yabe, M. Impact of salinity intrusion on rice productivity in the Vietnamese Mekong Delta. J. Fac. Agric. 63, 143-148 (2018).

68. Larson, C. Mekong Megadrought Erodes Food Security https://doi.org/10.1126/ science.aaf9880. (2016).

69. Hoang, L. P. et al. Mekong River flow and hydrological extremes underclimate change. Hydrol. Earth Syst. Sci. 20, 3027-3041 (2016).

70. Le, T. V. H., Nguyen, H. N., Wolanski, E., Tran, T. C. \& Haruyama, S. The combined impact on the flooding in Vietnam's Mekong River delta of local man-made structures, sea level rise, and dams upstream in the river catchment. Estuar., Coast. Shelf Sci. 71, 110-116 (2007).

71. Ritchie, H. \& Roser, M. Water Use and Sanitation http://ourworldindata.org/wateruse-sanitation. (2018).

72. Worldometers. World Population www.worldometers.info/. (2018).

73. Roser, M. Economic Growth ourworldindata.org/economic-growth. (2018).

74. Lu, C. \& Tian, H. Global nitrogen and phosphorus fertilizer use for agriculture production in the past half century: shifted hot spots and nutrient imbalance. Earth System Science. Data 9, 181-192 (2017).

75. Roser, M. \& Ritchie, H. Fertilizer andPesticides ourworldindata.org/fertilizer-andpesticides. (2017).

76. Tilman, D., Cassman, K. G., Matson, P. A., Naylor, R. \& Polasky, S. Agricultural sustainability and intensive production practices. Nature 418, 671 (2002).

77. Mbaye, S. \& Badia, M. M. New Data on Global Debt http://blogs.imf.org/2019/01/ 02/new-data-on-global-debt/. (2019).

78. The United States, Congress, House, Energy reorganization act of 1973: Hearings, Ninety-third Congress, first session, on H.R. 11510. p. 248, http://onlinebooks. library.upenn.edu/webbin/book/lookupid?key=ha000013418. (1973).

79. The Economist. The World If, Slowergrowth: A Disaster or a Blessing? worldif. economist.com/article/12121/debate. (2015).

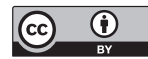

Open Access This article is licensed under a Creative Commons Attribution 4.0 International License, which permits use, sharing, adaptation, distribution and reproduction in any medium or format, as long as you give appropriate credit to the original author(s) and the source, provide a link to the Creative Commons license, and indicate if changes were made. The images or other third party material in this article are included in the article's Creative Commons license, unless indicated otherwise in a credit line to the material. If material is not included in the article's Creative Commons license and your intended use is not permitted by statutory regulation or exceeds the permitted use, you will need to obtain permission directly from the copyright holder. To view a copy of this license, visit http://creativecommons. org/licenses/by/4.0/.

(c) The Author(s) 2019 